\title{
PENGEMBANGAN POTENSI EKONOMI LOKAL DESA TOSARI KABUPATEN PASURUAN
}

\author{
Linda Dwi Rohmadiani dan Pradika Fersandi \\ Program Studi Perencanaan Wilayah dan Kota Fakultas Teknik Sipil dan Perencanaan \\ Universitas PGRI Adi Buana Surabaya \\ email: lindadwir@gmail.com
}

\begin{abstract}
ABSTRAK
Desa Tosari menjadi salah satu pintu gerbang wisata budaya Kabupaten Pasuruan, selain itu wilayah tersebut juga menjadi kawasan hutan lindung. Sehingga diperlukan adanya pembangunan yang berorientasi pada budaya lokal Suku Tengger. Penelitian ini bertujuan untuk merumuskan strategi pengembangan potensi ekonomi lokal masyarakat Desa Tosari berdasarkan kararkteristik wilayah. Pengumpulan data menggunakan metode wawancara. Alat analisis yang digunakan adalah Participatory Rural Appraisal (PRA), analisis SWOT dan EFAS IFAS. Berdasarkan hasil PRA dapat diidentifikasi potensi unggulan wilayah desa adalah pertanian khususnya komoditas kentang, sedangkan berdasarkan analisis SWOT dan EFAS IFAS strategi pengembangan potensi ekonomi lokal yang cocok bagi wilayah Desa Tosari adalah melakukan peningkatan kuantitas dan kualitas produksi pertanian, peningkatan nilai tambah komoditas pertanian, dan peningkatan kerjasama dengan swasta baik di sektor pertanian maupun pariwisata.
\end{abstract}

\section{Kata Kunci: partisipasi masyarakat, ekonomi lokal}

Desa Tosari became one of the gates of cultural tourism Pasuruan, besides the region is also a protected forest area. So necessary to the development of local culture oriented Suku Tengger. This research aims to formulate a strategy of local economic development potential Desa Tosari community based on its characteristics. Collecting data using interviews. The analysis tool used is the Participatory Rural Appraisal (PRA), SWOT analysis and EFAS IFAS. PRA can be identified based on the results of the excellent potential of the village is agriculture, especially potato, while based on the SWOT analysis and IFAS EFAS potential local economic development strategies suitable for Desa Tosari area is to increase the quantity and quality of agricultural production, the increase in the value added of agricultural commodities, and increased cooperation with the private sector both in agriculture and tourism.

\section{Keywords: community participation, local economy}

\section{PENDAHULUAN}

Pengembangan Ekonomi Lokal adalah suatu konsep yang menekankan perlunya menciptakan lapangan kerja bagi penduduk lokal dengan memanfaatkan sumber daya (alam, manusia, modal) setempat. Pengembangan Ekonomi Lokal ini merupakan upaya bersama antara masyarakat, pemerintah dan sektor swasta untuk mencapai competitive advantage dari wilayah lokal tersebut (Blakely, 1989 dalam Munir \& Fitanto, 2005). Pengembangan Ekonomi Lokal, adanya hubungan dengan dunia luar dianggap sebagai suatu kenyataan yang ada dan dimanfaatkan untuk kepentingan lokal.

Berdasarkan Peraturan Pemerintah Nomor 72 tahun 2007 tentang Desa, yang dimaksud Desa adalah sebagia kesatuan masyarakat hokum yang memiliki batas-batas wilayah, berwenang untuk mengatur dan mengurus kepentingan masyarakat setempat, berdasarkan asal usul dan adat istiadat setempat yang diakui dan dihormati dalam sistem pemerintahan Negara Kesatuan Republik Indonesia.

Desa Tosari secara umum adalah salah satu desa dari 8 (delapan) desa di-wilayah Kecamatan Tosari yang berada di lereng pegunungan dengan kondisi tanah yang berbukit-bukit dengan akses jalan berkelok-kelok, dan pegunungan tersebut adalah Pegunungan Tengger. Desa Tosari merupakan gerbang masuk wisatawan menuju Taman Nasional Bromo Tengger Semeru (TNBTS) dari arah Kabupaten Pasuruan. Luas wilayah penelitian sebesar $550.93 \mathrm{Ha}$ dengan mayoritas penggunaan lahan ialah lahan pertanian berupa sawah dan ladang sebesar 419,30 ha (76\% dari luas total wilayah).

Jumlah penduduk Desa Tosari tahun 2008-2012 terus mengalami peningkatan dengan ratarata pertumbuhan penduduk sebesar $2 \%$ pertahun. Berdasarkan hasil observasi dusun terpadat di 
Desa Tosari adalah Dusun Ledok Sari. Dominasi penggunaan lahan tersebut membawa pengaruh terhadap mata pencaharian utama masyarakat Desa Tosari di bidang pertanian. Sedangkan mata pencaharian tambahan masyarakat lokal adalah berdagang dan jasa penginapan dan hartop yang merupakan dampak dari aktifitas pariwisata di Taman Nasional Bromo Tengger Semeru (TNBTS).

Memperhatikan latar belakang diatas, maka yang menjadi tujuan penelitian ini adalah mengidentifikasi potensi ekonomi lokal Desa Tosari Kabupaten Pasuruan, dan menawarkan strategi yang dapat digunakan untuk pengembangan potensi ekonomi lokal Desa Tosari Kabupaten Pasuruan.

Hasil penelitian ini diharapkan dapat memberikan Pemerintah Kabupaten Pasuruan pedoman pembuatan kebijakan yang berkaitan dengan pembangunan Desa Tosari.

\section{METODE PENELITIAN}

Penelitian ini merupakan penelitian deskriptif kualitatif dengan pendekatan PRA (Participatory Rural Appraisa). Fokus penelitian ini adalah penggambaran secara menyeluruh tentang bentuk, fungsi, dan makna ungkapan larangan serta tidak melakukan perhitungan. Metode pengumpulan data dilakukan secara kualitatif dengan melakukan wawancara pada unit informasi yang telah dilakukan secara snow ball.

\section{HASIL DAN PEMBAHASAN}

\section{Potensi Ekonomi Lokal Desa Tosari}

\section{A. Pertanian}

Berdasarkan data Monografi Desa, potensi ekonomi yang dimiliki oleh Desa Tosari adalah Pertanian, Peternakan dan Jasa Pariwisata. Pertanian adalah sektor ekonomi dominan di wilayah penelitian dengan komoditas utamanya adalah tanaman kentang (Gambar 1).

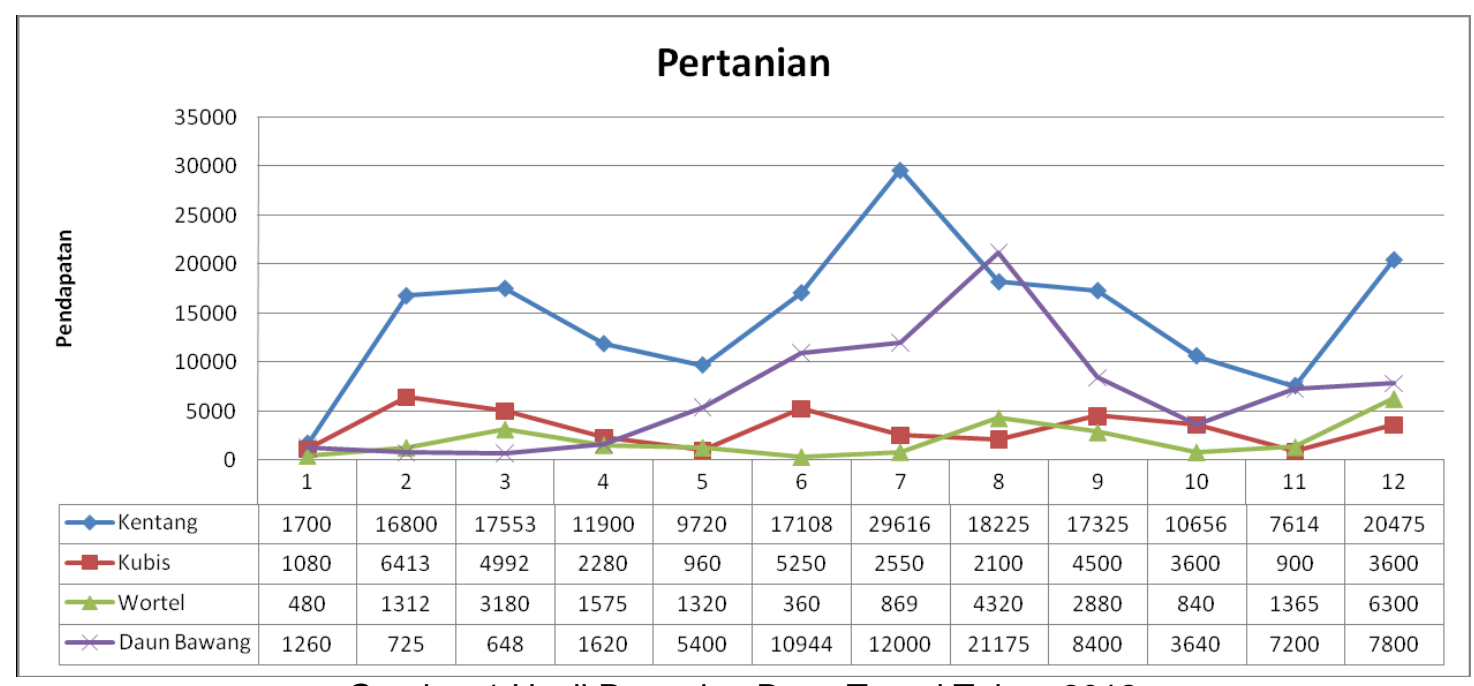

Gambar 1 Hasil Pertanian Desa Tosari Tahun 2012

Sumber: Monografi Desa Tosari, 2012

Tanaman kentang di Desa Tosari bukan tanaman musiman. Setiap bulan pasti ada lahan yang mulai membibit dan ada juga lahan yang mulai memanen hasil pertanian ini tetapi menanam kentang ter kendala dengan musim kemarau. Lahan pertanian yang memiliki sumber air sendiri akan melakukan pembibitan atau menanam seperti bulan-bulan biasanya. Tetapi untuk lahan pertanian yang tidak memiliki sumber mata air sendiri, biasanya pemilik lahan dan petani tidak melakukan penanaman atau dalam arti lahan pertanian dibiarkan kosong. Terkadang jika pemilik lahan ingin memanfaatkan lahannya dengan baik, pemilik lahan akan menanam gandum sebagai tanaman pengganti kentang. Karena gandum tidak memerlukan air yang terlalu banyak, sehingga pemilik lahan dan petani dapat menanamnya pada musim kemarau.

Selain komoditas kentang, Desa Tosari juga menghasilkan komoditas daun bawang merupakan komoditas yang ke dua di Desa Tosari dengan hasil yang terbanyak setelah kentang. Komoditas daun bawang juga mengalami naik turun seperti kentang. Hasil pertanian Daun bawang meningkat tajam di Bulan Agustus dan menurun di Bulan Maret. 
Selain itu juga ada komoditas kubis, wortel yang menjadi komoditas unggulan di Desa Tosari. Tanaman kubis dan wortel ini setiap bulannya juga mengalami naik turun. Tetapi tanaman ini menjadi tanaman sampingan. Tanaman yang yang tidak menjadi unggulan oleh para petani.

Ada juga komoditas jagung dan gandum. Komoditas ini ditanam setiap bulan oleh para petani. Petani tidak membiarkan lahan pertaniannya kosong. Hasil produksi komoditas jagung oleh petani tidak dijual ke pasar hanya untuk dikonsumsi sendiri oleh petani. karena jagung menrupakan bahan makanan pokok bagi masyarakat Tengger di Desa Tosari.

Ketika musim kemarau para petani beralih dari menanam kentang menjadi gandum, karena tanaman gandum tidak terlalu menyukai air jadi cocok ditanam pada musim panas. Bibit gandum diperoleh petani dari Dinas Pertanian setempat. Tanaman ini ditanam jika lahan para petani tidak mendapatkan irigasi yang baik. Sebaliknya jika lahan petani mendapatkan atau memiliki irigasi yang baik (sumber mata air) maka petani tetap menanam kentang. Kajian mata pencaharian sektor pertanian di wilayah penelitian pada tabel 1 .

Tabel 1 Kajian Mata Pencaharian Sektor Pertanian Tahun 2013

\begin{tabular}{|c|c|c|c|c|c|c|}
\hline \multirow{2}{*}{$\begin{array}{c}\text { Jenis } \\
\text { Kegiatan } \\
\text { (Usaha) }\end{array}$} & \multicolumn{2}{|c|}{ Tenaga Kerja } & \multirow[b]{2}{*}{ Pemasaran } & \multirow[b]{2}{*}{ Bahan Baku/ hasil } & \multirow[b]{2}{*}{ Bagaimana Mulai } & \multirow[b]{2}{*}{ Masalah } \\
\hline & $P$ & L & & & & \\
\hline Kentang & 1.212 & 1.137 & $\begin{array}{c}\text { Rp. } 3.000- \\
\text { Rp. } 6.000 / \mathrm{kg}\end{array}$ & $\begin{array}{l}\text { - } \text { Bibit lokal, mudah } \\
\text { didapat } \\
\text { - } \text { Mutu baik } \\
\text { - Jenis: Granola } \\
\text { Kembang, dll }\end{array}$ & $\begin{array}{l}\text { Turun-temurun } \\
\text { - Pengalaman } \\
\text { - Sekolah Lapang } \\
\text { Dinas Pertanian } \\
\text { Kab. }\end{array}$ & $\begin{array}{l}\text { - Musim panen, harga } \\
\text { jual turun tiba-tiba } \\
\text { - Cuaca, hama } \\
\text { - Penyakit } \\
\text { - Pupuk mahal }\end{array}$ \\
\hline Kubis & 1.212 & 1.137 & $\begin{array}{c}\text { Rp. } 500- \\
\text { Rp. } 3.000 / k g\end{array}$ & $\begin{array}{l}\text { - Bibit mudah } \\
\text { didapat } \\
\text { - Jenis: Kronet, } \\
\text { Hero, Grand 11, dll } \\
\text { - Mutu baik }\end{array}$ & $\begin{array}{l}\text { - Turun-temurun } \\
\text { - Pengalaman } \\
\text { - Sekolah Lapang } \\
\text { Dinas Pertanian } \\
\text { Kab. }\end{array}$ & $\begin{array}{l}\text { - Musim panen, harga } \\
\text { - } \text { Cual turun tiba-tiba } \\
\text { - penyakit } \\
\text { - Pupuk mahal }\end{array}$ \\
\hline $\begin{array}{l}\text { Bawang } \\
\text { Daun }\end{array}$ & 1.212 & 1.137 & $\begin{array}{l}\text { Rp. } 2.000- \\
\text { Rp. } 7.000 / \mathrm{kg}\end{array}$ & $\begin{array}{l}\text { - Bibit impor (taki) } \\
\text { dan lokal } \\
\text { - Mutu baik }\end{array}$ & $\begin{array}{l}\text { - Turun-temurun } \\
\text { - Pengalaman } \\
\text { - Sekolah Lapang } \\
\text { Dinas Pertanian } \\
\text { Kab. }\end{array}$ & $\begin{array}{l}\text { - Musim panen, harga } \\
\text { jual turun tiba-tiba } \\
\text { - Cuaca, hama } \\
\text { penyakit } \\
\text { - Pupuk mahal }\end{array}$ \\
\hline Worter & 1.212 & 1.137 & $\begin{array}{l}\text { Rp. } 500- \\
\text { Rp. } 4.000 / \mathrm{kg}\end{array}$ & $\begin{array}{l}\text { - Bibit lokal dari } \\
\text { Cipanas } \\
\text { - Mutu baik }\end{array}$ & $\begin{array}{l}\text { - Turun-temurun } \\
\text { - Pengalaman } \\
\text { Sekolah Lapang } \\
\text { Dinas Pertanian } \\
\text { Kab. }\end{array}$ & $\begin{array}{l}\text { - Musim panen, harga } \\
\text { - } \text { Cual turun tiba-tiba } \\
\text { - penyakit } \\
\text { - Pupuk mahal }\end{array}$ \\
\hline Jagung & 1.212 & 1.137 & $\begin{array}{l}\text { Dikonsumsi } \\
\text { sendiri }\end{array}$ & - Mutu cukup baik & - Turun-temurun & $\begin{array}{l}\text { Konsumsi sendiri } \\
\text { tidak dijadikan } \\
\text { sebagai tmbahan } \\
\text { pendapatan }\end{array}$ \\
\hline Gandum & 1.212 & 1.137 & - & $\begin{array}{l}\text { - Bibit mudah } \\
\text { didapat } \\
\text { - Mutu cukup baik }\end{array}$ & $\begin{array}{l}\text { - Penyuluhan Dinas } \\
\text { Pertanian } \\
\text { Kabupaten }\end{array}$ & $\begin{array}{l}\text { - Perontok biji gandum } \\
\text { besar, sulit dibawa } \\
\text { ke ladang }\end{array}$ \\
\hline
\end{tabular}

Sumber: Hasil Analisis, 2013

Hasil analisis survei yang telah dilakukan mengenai kajian mata pencaharian pertanian dapat ditarik kesimpulan bahwa sebagian besar penduduk Desa Tosari mata pencahariaanya sebagai petani. Komoditas pertanian di wilayah penelitian adalah kentang, kubis, bawang daun, wortel, jagung dan gandum. Tenaga kerja yang menggarap lahan pertanian yaitu untuk laki - laki sebesar 1.212 tenaga kerja dan untuk perempuan sebesar 1.137 tenaga kerja.

Pemasaran hasil pertanian kentang mengikuti harga pasaran yaitu mulai dari harga $\mathrm{Rp}$ 3.000 per $\mathrm{kg}$ sampai dengan harga $\mathrm{Rp} 6.000$ per $\mathrm{kg}$. Harga jual kentang baik dari petani, tengkulak maupun dari pasar, harganya standart mengikuti harga pasaran yang ada di Desa Tosari. Bibit kentang merupakan bibit lokal, mudah didapat dengan mutu baik. Bibit kentang biasanya didapat saat petani melakukan panen, saat panen hasil kentang yang masih kecil biasanya tidak dipasarkan melainkan digunakan untuk pembibitan tanaman selanjutnya. Bibit yang tidak sesuai dengan standart tidak dipergunakan dan langsung dibuang. Bibit kentang juga bisa didapat pada UPTD Dinas Pertanian Kabupaten Pasuruan yang berada di Desa Tosari.

Jenis kentang yang biasa ditanam oleh petani di Desa Tosari ini yaitu Granola Kembang. Para petani memulai menjadi petani yaitu turun temurun oleh keluarganya yang sudah 
berpengalaman. Sedangkan dari Dinas Pertanian Kabupaten Pasuruan sendiri memberikan sosialisasi SL (Sekolah Lapang) bagi para kelompok tani tentang penanaman kentang mulai dari awal sampai dengan pasca panen. Masalah yang dihadapi oleh petani kentang yaitu ketika panen mereka tidak mengetahui tentang pengolahan pasca panen karena hasil pertanian mereka langsung dibeli oleh tengkulak sehingga harga jual terkadang tiba - tiba bisa turun. Petani kentang juga tidak luput dari hama penyakit dan cuaca yang dapat merugikan hasil pertanian. Harga pupuk yang mahal juga menjadi kendala dari petani.

Pemasaran hasil pertanian Kubis mengikuti harga pasaran yaitu mulai dari Rp 500 sampai Rp 3.000 per kilogramnya. Bibit kubis diperoleh dengan mudah. Bibit yang diperoleh juga merupakan bibit yang mempunyai mutu baik. Jenis kubis yang ditanam di Desa Tosari berjenis Kronet, Hero dan Grand 11. Peatani kubis memulai menjadi petani kubis turun temurun dari keluarga terdahulunya yang sudah berpengalaman dalam bertani. Dinas Pertanian Kabupaten Pasuruan juga terkadang memberikan sosialisasi SL (Sekolah Lapang) tentang penanaman kubis yang baik dan benar. Permasalahan dari penanaman kubis juga hampir sama dengan kentang. Masalah yang dihadapi oleh petani kentang ketika panen mereka tidak mengetahui proses setelah panen karena hasil pertanian mereka langsung dibeli oleh tengkulak sehingga harga jual terkadang tiba - tiba bisa turun. Petani kentang juga tidak luput dari hama penyakit dan cuaca yang dapat merugikan hasil pertanian. Harga pupuk yang mahal juga menjadi kendala dari petani.

Pemasaran hasil pertanian bawang daun harganya mengikuti harga pasar dengan harga mulai dari Rp 2.000,- sampai Rp 7.000,- per kilogram. Bibit bawang daun di Desa Tosari ini bibit dengan jenis bibit impor (taki) dan bibit yang diperoleh dengan mutu baik. Para petani yang menanam bawang daun ini turun - temurun dari keluarga dan sudah berpengalaman serta dari pemerintah memberikan pelatihan SL (Sekolah Lapang) untuk membuka pola pikir petani dan mengetahui cara menanam sampai pasca panen dengan baik dan benar. Permasalahan dari petani kubis juga hampir sama dengan tanaman lainnya yang ditanam di Desa Tosari yaitu proses pasca panen, harga jual tiba - tiba turun, hama penyakit tanaman, cuaca dan harga pupuk yang mahal.

Hasil pertanian untuk wortel memiliki harga pasaran yang mengikuti harga pasar di Desa Tosari, yaitu mulai dari harga Rp 500,- sampai Rp 4.000,- per kilogramnya. Harga yang dipakai ini adalah harga standart yang ada di Desa Tosari. Bibit yang diperoleh merupakan jenis bibit lokal dan bibit dari Cipanas dengan mutu yang baik. Kegiatan menanam wortel ini diperoleh dari turun temurun keluarga petani yang telah mempunyai pengalaman. Dinas Pertanian juga member penyuluhan SL (Sekolah Lapang) untuk para kelompok tani yang ada di Desa Tosari yang berguna untuk membantu petani dalam mengatasi proses bertani yang baik dan benar. Permasalahan yang dihadapi oleh petani wortel juga sama dengan petani yang lain yaitu proses pasca panen, harga yang tidak menentu, hama penyakit yan belum dapat diatasi, cuaca yang berubah - ubah dan harga pupuk yang mahal sehingga sulit dijangkau oleh petani.

Hasil pertanian jagung merupakan pertanian yang tidak dijual oleh para petani, karena tanaman jagung merupakan tanaman yang hasilnya hanya dikonsumsi sendiri oleh para petani. Mengingat dari dahulu penduduk di Desa tosari makanan utamanya adalah jagung sehingga tanaman jagung hanya dikonsumsi sendiri tanpa adanya penjualan. Sehingga tidak adanya pemasaran dan patokan harga. Bibit jagung yang di peroleh merupakan bibit yang mempunyai mutu cukup baik. Jenis jagung yaitu jagung putih yang rasanya manis. Petani ini juga memulai menanam jagung turun - temurun dari keluarganya yang sudah berpengalaman. Permasalahan dari tanaman jagung yaitu tanaman jagung ini ditanam hanya untuk memenuhi kebutuhan keluarganya sendiri. Tanaman jagung ini juga tidak dapat dijadikan sebagai tambahan pendapatan petani.

Gandum merupakan tanaman yang ditanam di Desa Tosari hanya saat musim kemarau saja karena saat kemarau lahan petani yang tidak mempunyai sumber mata air sendiri tidak dapat menanam tanaman seperti kentang yang membutuhkan air banyak. Sehingga dari Dinas Pertanian memberikan penyuluhan bahwa saat musim kemarau lahan yang tidak mempunyai sumber mata air sendiri, melakukan penanaman gandum. Bibit yang diperoleh mudah di dapat dan mutunya baik. Bibit gandum biasanya diperoleh dari petugan dinas pertanian yang ada di Desa Tosari. Permasalahan yang dari penanaman gandum yaitu tidak adanya teknologi atau peralatan untuk merontokkan gandum secara instan, peralatan untuk perontokan gandum ini besar sehingga menyebabkan kurang efisiennya jika dibawa ke ladang dan selama ini perontokan gandung menggunakan peralatan manual.

Hasil panen yang tidak langsung dibeli dari lahan, hasil lahan dibawa ke Gudang, hasil panen disortir untuk memisahkan hasil yang akan dipasarkan dengan yang akan digunakan 
sebagai bibit sesuai dengan kriteria yang sudah ada. Melalui proses penyortiran hasil yang dipasarkan dapat langsung dijual ke pasar lokal atau dibeli oleh Tengkulak sesuai dengan harga yang telah disepakati. Namun pada umumnya Tengkulak lebih dominan dalam menentukan harga. Tengkulak memasarkan hasil pertanian sesuai permintaan baik dari Jawa maupun luar Jawa. Kemudian sebagian kecil dipasarkan ke Supermarket. Bibit dari hasil penyortiran kemudian digunakan untuk pembibitan hasil panen berikutnya. Bagan arus masukan dan keluaran komoditas pertanian di wilayah penelitian dapat dilihat gambar 2 .

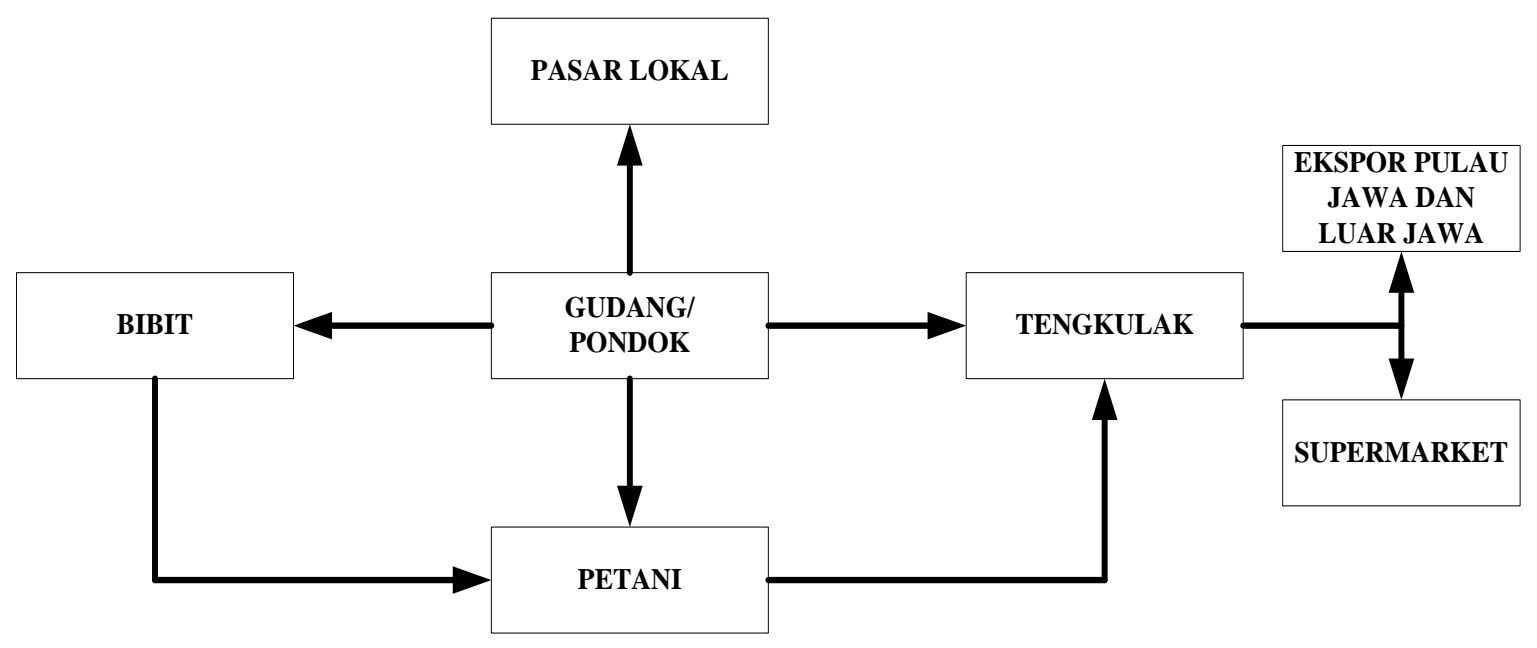

Gambar 2 Arus Masukan dan Keluaran Hasil Panen Komoditas Pertanian Tahun 2013 Sumber: Hasil Analisis, 2013

\section{B. Peternakan}

Peternakan di Desa Tosari bukan merupakan peternak yang besar. Peternak di Desa Tosari hanya memelihara ternaknya untuk keluarga sendiri dan tidak diperdagangkan. Tetapi jika ternak dari pemilik ternak ini ada yang ingin membeli, biasanya para pembeli langsung datang kerumah pemilik ternak. Hampir semua penduduk di Desa Tosari memiliki ternak sapi. Ternak sapi yang ada hanya sapi jantan, hali ini disebabkan karena kondisi alam Desa Tosari tidak cocok untuk mengembangbiakan sapi betina. Sapi betina di Desa Tosari tidak dapat berkembang akibat dari suhu dingin yang setiap hari menyelimuti desa tosari. Jadi peternak di Desa Tosari hanya memelihara sapi atau biasa disebut peternak rumahan saja tanpa memperdagangkan sapinya.

Hasil analisis kompilasi data mengenai kajian mata pencaharian peternakan yaitu sebagian besar penduduk Desa Tosari memiliki ternak. Tetapi peternakan yang ada di Desa Tosari bukan merupakan peternakan besar yang hasilnya diperdagangan, melainkan peternakan yang hanya dijadikan peliharaan saja. Tenaga kerja yang berternak ini hampir setengah dari jumlah penduduk. Karena di Desa Tosari penduduknya mempunyai peternakan sendiri - sendiri. Sehingga membuat hampir setengah penduduknya melakukan pekerjaan ini sendiri. Jika di asumsikan tenaga kerja laki - laki berjumlah 606 tenaga kerja dan untuk jumlah tenaga kerja perempuan yaitu sejumlah 568 tenaga kerja.

Untuk pemasaran dari perternakan sendiri tidak terlalu dominan memasarkan. Karena ternaknya tidak di perjual belikan. Tetapi biasaya jika ada pembeli yang akan membeli ternak milik peternak ini, pembeli langsung membeli ternak tersebut ke rumah pemilik ternak tersebut. Karena pemilik ternak hanya memelihara saja tanpa memperdagangkan.

Hewan yang akan dipelihara oleh pemilik ternak ini diperoleh dari pasar ternak yang berda di Desa sebelah yaitu Desa Nongkojajar. Disana pemilik ternak membeli hewan ternak dengan kualitas yang baik untuk dipelihara. Hewan ternak yang akan dibeli oleh peternak ini dibeli dari masih kecil dan dengan mutu yang baik pula (Gambar 3). 


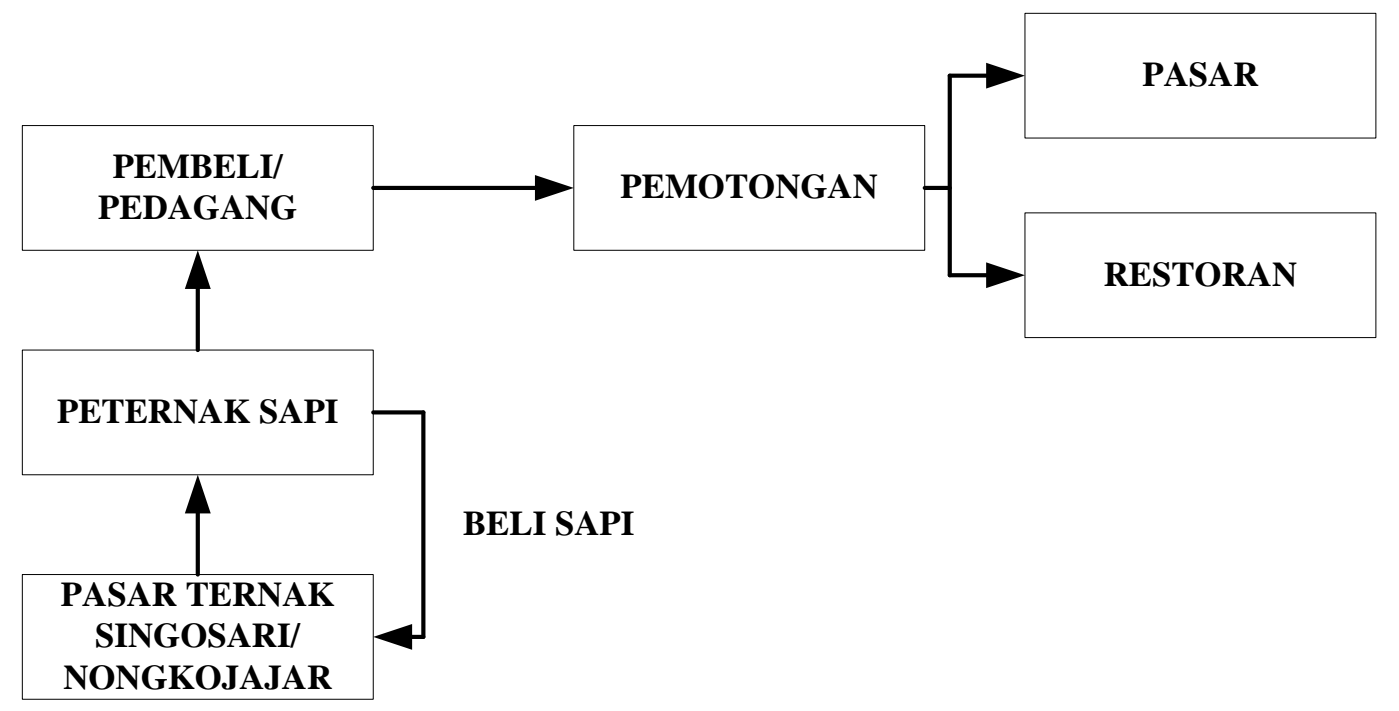

Gambar 3. Arus Masukan dan Keluaran Ternak Sapi Tahun 2013

Sumber: Hasil Analisis, 2013

Peternak memulai melakukan ternak sapi ini sejak dahulu dan dengan melalui insting peternak. Dalam arti dimana pada saat itu peternak mencoba melakukan pemeliharaan awal, dan mencoba apakah pemeliharaan ini cocok untuk dilanjutkan berternak. Lebih jelasnya dapat dilihat pada tabel 2.

Tabel 2 Kajian Mata Pencaharian Sektor Peternakan Tahun 2013

\begin{tabular}{|c|c|c|c|c|c|c|}
\hline \multirow{2}{*}{$\begin{array}{c}\text { Jenis } \\
\text { Kegiatan } \\
\text { (Usaha) }\end{array}$} & \multicolumn{2}{|c|}{ Tenaga Kerja } & \multirow[b]{2}{*}{ Pemasaran } & \multirow{2}{*}{$\begin{array}{l}\text { Bahan Baku/ } \\
\text { hasil }\end{array}$} & \multirow{2}{*}{$\begin{array}{l}\text { Bagaimana } \\
\text { Mulai }\end{array}$} & \multirow[b]{2}{*}{ Masalah } \\
\hline & $\mathrm{P}$ & L & & & & \\
\hline Sapi & 606 & 568 & Peliharaan & - Mutu baik & - Insting & $\begin{array}{l}\text { - Tidak ada sapi betina } \\
\text { - Karena cuaca jadi } \\
\text { sulit berkembang }\end{array}$ \\
\hline
\end{tabular}

Sumber: Hasil Analisis, 2013

\section{Jasa Pariwisata}

Jasa homestay atau lebih dikenal dengan tempat peristirahatan atau penginapan yang ada di Desa Tosari ini baru-baru saja tersedia. Yang paling dominan menyediakan jasa penginapan adalah Dusun Tosari dan Dusun Tlogosari. Karena dianggap dusun tersebut mempunyai letak yang dekat untuk kemudian melanjutkan perjalanan menuju tempat Pariwisata Gunung Bromo.

Jasa penginapan yang ada di Desa Tosari ada karena masyarakat sekitar beranggapan bahwa apabila tempat penginapan yang ada di Desa Wonokitri penuh para wisatawan yang ingin berkunjung ke Gunung Bromo mau tidak mau mencari alternatif tempat penginapan yang lain yang jaraknya tidak jauh dari lokasi pariwisata Gunung Bromo, karena Desa Wonokitri yang terletak di lereng Gunung Bromo dan menjadi akses keluar masuk menuju Gunung Bromo maka Desa Tosari merupakan alternatif kedua yang menjadi ilihan tempat penginapan.

Desa Tosari terdapat satu Hotel yaitu Bromo Cottages, yang sebenarnya letak hotel ini diluar batas Desa Tosari yaitu Desa Baledono yang secara kebetulan hotel tersebut menghadap ke Desa Tosari karena Desa Tosari merupakan akses yang dekat menuju kawasan Wisata Gunung Bromo.

Jasa hartop atau mobil jeep yaitu jasa penyewaan transportasi untuk menuju kawasan Wisata Gunung Bromo karena letaknya yang sulit ditempuh jika menggunakan transportasi mobil pribadi lainnya. Hartop merupakan kendaraan khusus yang biasanya digunakan untuk melewati medan yang berat khususnya, seperti medan yang menuju kawasan Gunung Bromo. Medan yang menanjak dan melewati padang pasir, hartop merupakan kendaraan 4wd yang khusus dipakai untuk melewati medan tersebut.

Jasa penyedia hartop di Desa Tosari baru mendominasi, hampir tiap rumah mempunyai mobil tersebut. Bahkan ada satu orang yang memiliki lebih dari satu hartop. Karena mengingat 
akses terdekat menuju Kawasan Wisata Gunung Bromo menjadikan salah satu alternatif penyedia jasa transportasi di Desa Tosari. Lebih jelasnya dapat dilihat pada tabel 3.

Tabel 3. Kajian Mata Pencaharian Jasa Pariwisata Tahun 2013

\begin{tabular}{|c|c|c|c|c|c|}
\hline Jenis & Tenaga Kerja & Pemasaran & Bahan Baku/ & Bagaimana & Masalah \\
\hline $\begin{array}{c}\text { Kegiatan } \\
\text { (Usaha) }\end{array}$ & & & & & \\
\hline $\begin{array}{l}\text { Jasa } \\
\text { penyewaan } \\
\text { hartop }\end{array}$ & 50 & $\begin{array}{l}\text { Rp. } 300.000- \\
\text { Rp. } 400.000 / \text { mobil } \\
\text { Konsumen turis } \\
\text { lokal dan } \\
\text { mancanegara }\end{array}$ & $\begin{array}{l}\text { Pendukung } \\
\text { wisata Gn. } \\
\text { Bromo }\end{array}$ & $\begin{array}{l}\text { Tumbuh } \\
\text { sendiri }\end{array}$ & Makelar \\
\hline Homestay & 50 & $\begin{array}{l}\text { Rp. } 300.000- \\
\text { Rp. } 600.000 / \text { hari } \\
\text { Konsumen turis } \\
\text { lokal dan } \\
\text { mancanegara }\end{array}$ & $\begin{array}{l}\text { Pendukung } \\
\text { wisata Gn. } \\
\text { Bromo }\end{array}$ & $\begin{array}{l}\text { Tumbuh } \\
\text { sendiri }\end{array}$ & Musiman \\
\hline
\end{tabular}

Sumber: Hasil Analisis, 2013

Alur pemesanan jasa hartop adalah pemilik penginapan ke Paguyupan Hartop kemudian menugaskan hartop sesuai dengan nomor lambung. Pemesanan jasa hartop bekerja sama dengan pemilik penginapan. Namun permasalahan yang dialami oleh Paguyupan Hartop adalah adanya makelar, sopir Hartop harus memberikan uang tips kepada makelar sehingga mengurangi pendapatan sopir. Bagan arus masukan dan keluaran jasa persewaan hartop dan penginapan dapat dilihat pada gambar 4 dan 5 .

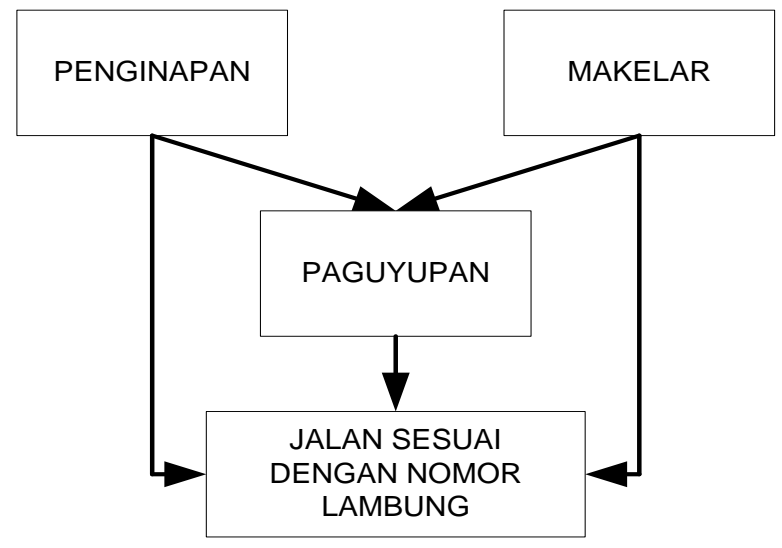

Gambar 4. Arus Masukan dan Keluaran Jasa Persewaan Hartop Tahun 2013 Sumber: Hasil Analisis, 2013

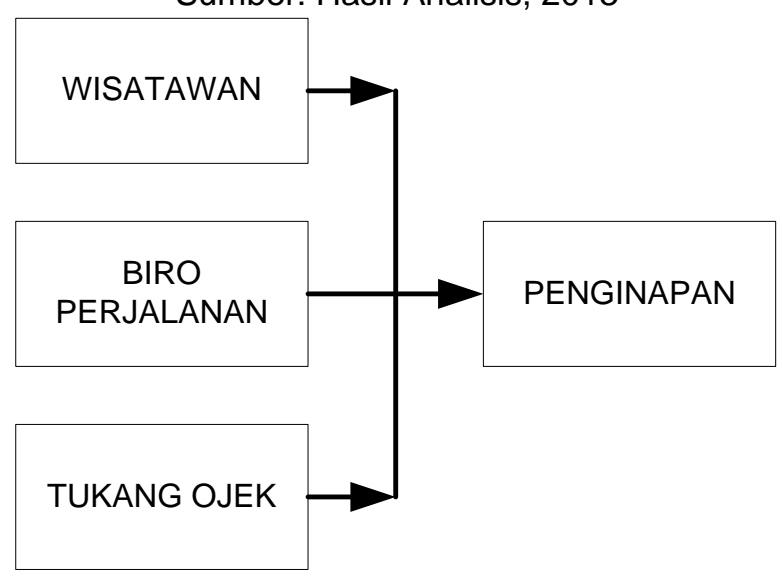

Gambar 5. Arus Masukan dan Keluaran Jasa Penginapan Tahun 2013 Sumber: Hasil Analisis, 2013 


\section{Strategi Pengembangan Potensi Ekonomi Lokal Desa Tosari}

Strategi pengembangan potensi ekonomi lokal di wilayah penelitian yang diperlukan adalah memperluas kerjasama dengan pemerintah dan swasta dalam rangka peningkatan teknologi pertanian, peningkatan nilai tambah hasil produksi pertanian sehingga mampu bersaing dengan komoditas dari luar daerah, serta peningkatan kuantitas dan kualitas infrastruktur pendukung sektor pertanian dan pariwisata pegunungan. Selain itu juga kualitas sumber daya manusia juga perlu ditingkatkan kualitasnya. Mengingat lokasi wilayah penelitian masuk dalam kawasan rawan bencana longsor dan kawasan konservasi Taman Nasional Bromo Tengger Semeru sehingga diperlukan adanya pengendalian konversi hutan menjadi lahan pertanian.

\section{KESIMPULAN}

Berdasarkan penjelasan hasil penelitian maka dapat diuraikan beberapa kesimpulan yaitu: (1) potensi alam yang di Desa Tosari sangat cocok untuk pertanian perkebunan khususnya tanaman kentang dan pariwisata pegunungan. Budaya masyarakat desa yang menganggap kegiatan pertanian merupakan kegiatan turun temurun dan harus dipertahankan. Kegiatan pariwisata yang berkembang merupakan dampak dari kedekatan wilayah desa dengan Taman Nasional Bromo Tengger Semeru. 2) Strategi pengembangan potensi ekonomi lokal di wilayah penelitian dengan cara pengembangan kerjasama dengan pemerintah dan swasta baik di sektor pertanian dan pariwisata pegunungan. Kerjasama di bidang pertanian misalnya peningkatan teknologi pertanian dan peningkatan nilai tambah hasil pertanian yang bisa digunakan sebagai pendukung kegiatan pariwisata pegunungan.

\section{UCAPAN TERIMA KASIH}

Penulis Linda Dwi Rohmadiani mengucapkan terima kasih Badan Perencana dan Pembangunan kabupaten Pasuruan, Aparat Desa Tosari dan seluruh mahasiswa Perencanaan Wilayah dan Kota Angkatan 2011 khususnya Kelompok Desa Tosari atas bantuan survey.

\section{DAFTAR PUSTAKA}

Allen, John C, Rebecca Filkins and Sam Cordes. 2000. Alternative Development Strategies for Rural Communities: Views from the Great Plains. Department of Agricultural Economics, University of Nebraska-Lincoln. Washington DC.

Anomim. 2004. Best Practices in Rural \& Small Town Economic Development. Rick Hundey Management and Planning Services. Canada

Anonim. 2012. Rural Economic Development Initiative (REDI). Division of Community Development Florida Department of Economic Opportunity. Florida.

Chambers, Robert. 1994. The Origins and Practice of Participatory Rural Appraisal. World Development Institute of Development Studies, Brighton.

Cohen, M., John. Uphoff, T., Norman. 1977. Rural Development Participation: Concepts and Measures for Project Design, Implementation and Evaluation. Ithaka. Cornel University

Musa, John Jiya. 2010. Nigeria's Rural Economic Development Strategy: Community Driven Development Approach. Department of Agricultural Engineering, Federal University of Technology. Minna, Nigeria.

Soetomo. 2006. Strategi-strategi Pembangunan Masyarakat. Yogyakarta: Pustaka Pelajar.

Sumners, Joe A. and Larry Lee. 2012. Crossroads and Connection. Auburn University.

Susantyo, Badru. 2007. Partisipasi Masyarakat Dalam Pembangunan di Pedesaan. Jurnal Informasi Vo. 12, Nomor 03 Tahun 2007. 